\title{
ENHANCING STUDENTS' PROBLEM IDENTIFICATION IN TRANSLATION TEACHING IN AN ENGLISH LANGUAGE PROGRAM
}

\author{
Nguyen Thi Thu Huong* \\ University of Foreign Language Studies, University of Danang, \\ 131 Luong Nhu Hoc, Cam Le, Danang, Vietnam
}

Received 16 April 2020

Revised 07 June 2020; Accepted 22 July 2020

\begin{abstract}
Teaching translation in Vietnam and other contexts tends to overemphasise linguistic issues in translation and lack focus on students' translation process. Drawing on a functional approach to translation, this pedagogical study investigates students' identification of translation problems (part of strategic competence) in a translation course in a tertiary English language program. The differences in students' ability to identify translation problems were evaluated through a contrastive examination of a qualitative analysis of students' written reflections on the translation tasks and their translation solutions both before and after the workshops. The study found that students diverted their attention from linguistic problems to other non-linguistic ones (extralinguistic issues related to extratextual features and general style conventions) after the workshops. This change led to some students' attempts to avoid word-forword translation and produce more idiomatic translation solutions as shown in the analysis of titles. Recommendations were made on the inclusion of text analysis and problem identification in developing students' translation skills.
\end{abstract}

Keywords: translation teaching, translation process, translation problems, translation problem identification, text analysis

\section{Introduction}

The pressures caused by the increased global and local demand for translation services and the lack of professional translator training in Vietnam are directed to translation courses in foreign language programs at the tertiary level which are expected to train graduates with adequate skills for employment. Nevertheless, graduates of English programs

\footnotetext{
* Tel.: 84-787582425

Email: huong2kh@gmail.com; ntthhuong@ufl.udn.vn

This research is funded by Funds for Science and Technology Development of the University of Danang under project number B2019-DN05-25
}

in Vietnam who are often expected to engage in professional translation work usually lack the skills and ability to do so (Ho \& Bui, 2013; T. T. Nguyen, 2010). This can be linked with the problematic translation teaching at the tertiary level in Vietnam, which is usually part of language programs. Some studies (Ho and Bui, 2013; T.T. Nguyen, 2010; Pham and Ton, 2007; Pham and Tran, 2013) reported that students' translation ability was limited due to their lack of an adequate understanding of the source text and their difficulties in finding target language equivalents. Students also complained that they were not equipped with translation strategies and analytical 
ability in dealing with a translation task. Ho and Bui (2013) found that the most common problems encountered by students are related to word usage and grammar errors. In other words, students mainly focus on linguistic aspects of translation and linguistic problems and in many cases and they tend to produce too literal or word-for-word translations.

Other studies done in many countries including Indonesia, Iran, China and Thailand (Avval, 2013; Chen, 2010; Saleh \& Weda, 2018; Wongranu, 2017) reported similar problems in translation teaching. Saleh and Weda (2018) who investigated the poetry translation of students in an English program in an Indonesian university revealed that many students had problems and difficulties in translating vocabulary and sentence structures. Wongranu (2017) found that students in Thailand made grammatical errors due to their use of read and translate procedures and they produced too literal translation. This led to students' anxiety and lack of confidence in translating. In these classes, teachers hadthe tendency to draw students' attention to the source text (ST) and its linguistic translation problems. One possible explanation for the overemphasis of linguistic issues and the resulting impact on students' translation is that both educators tend to be more interested in linguistic differences than students' analytical skills and strategies in translation.

While translation is still considered a purely linguistic activity in several contexts, many researchers (Carreres \& NoriegaSánchez, 2011; Cook, 2010; Leonardi \& Salvi, 2016) in their efforts to improve students' translation agree that translation is a communicative act that refers to the use of translation in a particular situation. They maintain that instead of overemphasising linguistic issues and students' linguistic capacity in translation, educators should pay attention to other translation issues including problems with text types or translation situations. This study adopts the view of the functional approach to translation which goes beyond the linguistic issues in raising students' awareness of different translation problems and improving their translations. The study will inform translation teaching at the tertiary level in Vietnam and other countries.

\section{Literature review}

This section presents problem identification and justification in teaching translation. It will also present key elements of the functional approach to translation that will be beneficial to enhancing students' ability to identify problems and justify their translations.

\subsection{Problem identification and problem- solving}

Problem identification and justification are considered aspects of translator's strategic subcompetence, a component of translator competence by a translation research group called PACTE (2008) (Fernández and Zabalbeascoa, 2012a, b). Strategic subcompetence "creates links between the different subcompetences (eg., bilingual, extra-linguisitic, instrumental and psycho-physiological competentences) as it controls the translation process" (PACTE, 2008, p.107). By activating the other subcompetences, strategic subcompetence maintains the efficiency of the translation process by enabling translators to identify translation problems and apply procedures and methods to solve the problems.

Although PACTE's definition and strategic subcompetences are specific to professional translator training, it is relevant to translation 
teaching at tertiary level where students' strategic awareness of the translation process is crucial. Many process-oriented pedagogical proposals including those by Kokkinidou and Spanou (2013), Lee and Gyogi (2018) and Leonardi (2010) have attended to developing students' translation process as part of their translation skill development. Processoriented pedagogical approaches allow learners to be conscious of varied factors in the translation process and make informed translation decisions.

In this study, the translation process derives from Gile's (2009) model of translation that includes: comprehension of the ST and reformulation or production of the target text (TT). Gile explains that the actual process involves the translator reading the whole ST to identify problems and their attempting to solve them; therefore, the translation process can refer to problem identifying and problem-solving. It is possible to propose a definition of translation problem at this stage. A translation problem refers to a text segment (verbal or non-verbal) that is either at micro level (i.e., a text segment) or at macro level (i.e., at the text level) and that requires the translator to consciously apply a justified translation strategy (González-Davies \& Scott-Tennent, 2005). This definition indicates the interrelated counterparts of problems and strategies. In translation, problems and difficulties can be identified in both phases: comprehending the ST and producing the TT. The problems and difficulties are then solved by translation strategies. This study will look into students' reporting of their problems and difficulties in translation and their solutions or strategies to some of the ST items. The next section introduces elements of the functional approach to translation in promoting students' problem identification.

\subsection{A functional approach to translation: text analysis, translation briefs and types of problems}

The functional approach to translation emphasises "skopos", or function which determines how a translated text is produced (Nord 1997). Translation must be fit or adequate for purpose. A text may be translated in several ways depending on the TT purpose which can be assigned by the initiator (a person who requires the translation). This approach has marked a transition from the linguistic view of translation (i.e., translation is considered a linguistic contrastive analysis activity) to a communicative intercultural activity (Schäffner \& Wiesemann, 2001).

Nord's model has its practical use in translator training as students' competence in translation can be developed by taking into account the three aspects: ST analysis, the translation brief, and the hierarchy of translation problems (Nord 1997). Text analysis refers to the analysis of both extratextual and intratextual factors of the ST and TT. Extratextual factors include "sender" (text producer or writer), "sender's intention", "audience" (reader), "medium" (channel), "place of communication", "time of communication", "motive for communication" (why a text is produced), and "text function". Intratextual factors include subject matter, content, presupposition, text composition (or structure), non-verbal elements, lexis, sentence structure and suprasegmental features (e.g., italic or bold type). While ST analysis promotes translator's understanding of the ST, translation brief enables the translator to establish why a translation is required and by whom, what the clients need, and when, where the TT will be used, and who the TT addressees are.

As of translation problems, Nord's 
translation problems are pragmatic (related to differences in the situations of the ST and TT), cultural translation problems (related to cultural differences), linguistic (related to differences between languages), and textspecific (e.g. metaphors or puns). Nord (1997, 2005) advocates that the translator should, in the first place, consider pragmatic perspectives in doing translation, giving priority to problems arising from the situations of the ST and the TT and the function of a translation. Nord differentiates between translation difficulties and translation problems. While difficulties are subjective and dependent on each translator, problems are more objective and seem to exist regardless of the level of translators.

A number of studies have proposed the incorporation of functionalist insights, particularly those of Nord into translation teaching in language programs. Colina and Lafford (2018) illustrate examples of translation activities that focus on the effects of contextual features (e.g., text, author, reader, and function) on understanding and producing texts. They include authentic texts and translation briefs so that students can understand how authentic texts are constructed in various genres, fields and contexts, keeping in mind different purposes and readers. Specifically, to assist students in their translation processes, the authors introduce both top-down and bottom-up genre-based approaches to text analysis where different elements of texts are considered.

Károly (2014) adopts a functional approach in supporting the enhanced status for translation in English language teaching. The author implemented the functional theoretical framework into foreign language programs with the aim of developing students' language and translation competence in an undergraduate English program in Hungary. After text analysis activities based on Nord's (2005) functional text analysis model were introduced in teacher-student, group and class discussions, the students had one week to translate three texts of different genres with translation briefs. The students' translations and discussions of the TT were analysed to identify and explore students' translation problems and difficulties (based on Nord's category of problems). The study found that linguistic problems were common among the students while they could identify other pragmatic and convention-related problems. The study illustrated the effective use of a functional translation approach in terms of students' identification of Nord's translation problems and difficulties. However, the study was implemented on a small scale, and it was mainly focused on data on students' errors that resulted from students' inability to deal with translation problems. To have a better insight into the process of problem identification, further research on students' reflections on their processes is needed.

Chen's (2010) study demonstrates the feasibility of incorporating functional approaches into translation teaching in general and Nord's model in particular in English programs. Text analysis, particularly consideration of text type and text function enables students to make any changes that fulfil communicative function(s) of a translation. The study particularly focused on the problem-solving process in which students identified problems in translating a ST item (i.e., metaphors) and adopted strategies to deal with them. The study reported a considerable change in students' treatments of metaphors. A student, for example chose to omit the metaphor in the translation due to a change in the function of the translation. Despite the strengths, the 
research had some methodological flaws. The same texts and examples of metaphors were used in the experimental teaching and the post translation task, which questioned the validity and reliability of the results. Analysis of the students' translations into English could have been affected due to their lack of competence in English. The present study presents qualitative data on the changes in students' translation process while translating into Vietnamese L1 before and after the experimental teaching in a series of workshops.

The study aims to answer the following questions:

1. What translation problems and difficulties do the students notice before and after the workshops?

2. How are students' translations different before and after the workshops?

\section{Methods}

\subsection{Participants}

Thirty students who were taking the introductory translation course (Translation 1) in a Vietnamese foreign language university were recruited to participate in this study. The participants had completed their first two years of skill training in English and other areas (e.g., computer skills). The students had taken compulsory courses in integrated English skills which aimed to help them consolidate level B1 English proficiency after the first year and achieve level B2 after the second year. Some written errors are still common among B2 students. During their first two years, the students had not undertaken any courses in translation.

\subsection{The research procedure}

Firstly, 30 third-year students performed Translation Task 1 in which they translated two texts and wrote about the difficulties they encountered during their translation processes. The second procedure involved the participation of the 30 students in three consciousness raising (CR) workshops. Lastly, all of the 30 students completed Translation Task 2, which was similar to Translation Task 1.

\subsection{Translation workshops}

There were three 150-minute workshops, each of which consisted of three 50-minute sections. Workshop 1 drew the students' attention to the notion of a good translation through discussions of their previous assumptions about translation, and their general ideas about their types of text encountered. Workshop 2 focused on text analysis which include different elements of texts and translation briefs or translation instructions. Specifically, the students were asked to translate one passage with and without translation briefs and they were then asked to identify differences in their translations. The aim of this activity is to develop the students' awareness that the translation brief enables the translator to make informed decisions during the decision-making process. I did not include types of translation problems in order to avoid bias during the study. In Workshop 3 , the students were asked to identify the used strategies in the published Vietnamese translations and discussed the appropriateness of the strategies. This would lead to the students' awareness that the choice of strategy is based on text features, and the translation brief. In the final part of the workshop, the students were encouraged to write about what they considered to be accurate or what they thought constituted a good translation.

\subsection{Translation tasks}

Before and after the translation workshops, students were asked to do similar 
translation tasks. Each translation task consisted of two smaller tasks (Text 1a and Text 1b-carried out before the workshops; Text $2 \mathrm{a}$ and Text $2 \mathrm{~b}$-carried out after the workshops). Each task sheet featured a section for the students' translation, followed by a section for their comments about the problems and difficulties they encountered while translating (Writ. 1-comments before the workshops; Writ. 2-comments after the workshops). The translation tasks were similar in terms of structure, reference tools, time allocation and text length, translation to first language (L1) direction, text types, topics, text complexity, text features, students' flexibility with text sequence, and translation briefs (or instructions). The translation task design and the choice of texts, on the one hand, was appropriate to students' English proficiency to facilitate their comprehension and enable them to perform well within their capacity. On the other hand, the abovementioned considerations allow for an optimal investigation of students' awareness of the translation process.

\subsection{Written comments}

After translating, the students were asked to write at least five of the problems and difficulties they had in doing the translation. The students' written comments followed the principles of the Integrated Problem and Decision Report (IPDR) developed by Gile (2004). The IPDR is a tool for studying the students' decision-making process in translation. Students are asked to note their problems and decisions in the translation task. According to Gile, students' notes can reflect their thoughts during the translation process and provide "information about students' problems, both individual and collective, and information about their translation strategies" (Gile, 2004, p. 2). The data analysis included students' comments in English which contained some inaccuracy due to their limited English proficiency.

\section{Results and discussion}

This section presents the results about students' reflections about their problems and difficulties before and after translation workshops. The analysis of students' translations to some ST items is also included to demonstrate relations between problem identification and translation solutions.

\subsection{Students' problems and difficulties}

Table 1. Total numbers of translation problems and difficulties

\begin{tabular}{llcc}
\hline \multicolumn{1}{c}{ Types of problems } & $\begin{array}{c}\text { Written comment } \\
1\end{array}$ & $\begin{array}{c}\text { Written comment 2 } \\
\text { (after the } \\
\text { (before the } \\
\text { workshops) }\end{array}$ & (3) \\
\hline $1 \quad$ Difficulties related to extratextual features & 2 & 8 \\
Author & 1 & 19 \\
Reader & Text function & 6 & 52 \\
& Subtotal & 6 & 16
\end{tabular}


3 Difficulties related to vocabulary and expressions

$\begin{array}{lcc}\text { ST comprehension } & 34 & 20 \\ \text { TT production* } & 28 & 25 \\ \text { Both ST comprehension and TT production } & 2 & 1 \\ \text { Unspecified difficulty** } & 18 & 24 \\ \text { Sub-total } & 82 & 70 \\ \text { Difficulties related to sentences and sentence structures } & & \\ \text { ST comprehension } & 3 & 2 \\ \text { TT production* } & 9 & 6 \\ \text { Both ST comprehension and TT production } & 0 & 1 \\ \text { Unspecified difficulty** } & 1 & 9 \\ \text { Sub-total Total } & 13 & 18 \\ & 107 & 136\end{array}$

* TT production: the difficulty in producing the provisional TT segment.

** Unspecified difficulty: The students copied the language in the ST and they did not specify whether the difficulty was related to ST comprehension or TT production. As there was not information about the students' problem, this category was not given a detailed analysis. Nevertheless, it still counted in the subtotal in each category.

In the analysis, the students' comments were classified into translation problems and difficulties related to extratextual features, general style conventions, vocabulary and expressions, and sentences and sentence structures (Table 1 above).

\subsubsection{Difficulties related to extratextual features}

The translation problems related to extratextual features referred to the students' comments about extratextual features including the author and text function. That the students' raised an issue was itself a sign of progress or improvement, notwithstanding the nature of their comments.

Before the workshops, very few comments referred to difficulties related to extratextual features. The students made only six comments about problems related to the author, the text function and the reader; however, the students did not elaborate on these problems. Three comments were concerned with the expression of the author's intentions (e.g., "I can't express all emotion which author want to convey" (Student 1, Writ. 1) or "Choose the meaning of words to be suitable for the intention of writer" (Student 19, Writ. 1). Two students referred to the text function and/or the reader. Student 28 was concerned about how target readers would comprehend their translation while briefly noting "the purpose of this text". Student 8's comment referred to text function by stating that the reader should be persuaded to do something (i.e., "carry out such as the target"). However, what Students 28 and 8 meant by text function was not clearly indicated.

Style: It is difficult to express the source text and persuade the reader carry out such as the target. (Student 8, Writ. 1)

After the workshops, the number of problems and difficulties was five time higher (32 versus 6). Firstly, eight comments referred to problems related to the author and understanding the author's intention (e.g., Students 4 and 10). Some other students (1, 18 and 21) also expressed difficulties in rendering 
the intentions, messages, and feelings of the author. Student 1 referred to the "feeling of author" in translating the "dead leaf blown in the wind" for which she used a word-for-word translation strategy. However, the reason for her dissatisfaction with her solution was not revealed.

Maybe I still don't express all feeling of author for "dead leaf blown in the wind." (Student 1, Writ. 2)

Secondly, after the workshops, some students indicated the difficulties they experienced in identifying and maintaining the purpose of the translation. Student 23 stated that they had difficulty defining the purpose of Text $2 b$ ("I have problem when I have to define the type of text, purpose of text"). Student 1 referred to the function of the text ("persuasive") to the specific text type ("advertisement"- Text 2awhich is a government fact sheet, though). Similarly, Student 22 raised the problem of their translation's informative function ("my translation don't give information clearly"). Student 11 cited "easy green cleaning" in referring to their difficulty with "the goal of text". These students could have kept in mind the function or the purpose of translation in translating. However, as they did not elaborate much on their comments, it was hard to explore their understanding of text function, how it affected their translation solutions, and whether it played a role in their reflections on their translations.

Finally, in post-workshop written reflections, 19 comments (nearly two-thirds of the subtotal of the difficulties related to extratextual features) were devoted to the difficulties in determining the reader and translating for the reader. Compared with author and text function, the students elaborated further on this feature and they were able to see the importance of considering the reader in translating. For example, Student 21 maintained that, "You must define the reader (the receptor) and translate are accord". Only one comment pertained to the student's inability to determine who the reader was ("I don't know exactly who the readers are", Student 1, Writ. 2) while 14 comments clearly indicated who the translations targeted (e.g., children, Vietnamese children, or Vietnamese communities in Australia). In some cases, responses indicated that once the students were able to identify their reader, they seemed to be confident with their translation solutions, for example, to "green cleaning" in Title $2 \mathrm{a}$ (Text 2a)- "Easy Recyling-Create Your Own Eden" (Students 4 and 19) and "he" in Text 2b (Student 4).

Reader is Vietnamese communities in Australia, so I used exactly the word "green cleaning”. (Student 4, Writ. 2)

After the workshops, students' reference to readers and/or other extratextual features suggested the impact of the workshops in which the students were instructed to consider the issue of readers and other extratextual features. Using the information in the translation brief they were given about the reader (i.e., Vietnamese communities in Australia), Students 4 and 19 justified their keeping the English ST "green cleaning" in their Vietnamese translations. Even though the solution did not match that of the published translation, this solution type was reasonably justified by the students.

The volume of comments on problems related to extratextual features after the workshops was five times the number raised in the corresponding evaluations completed prior to the workshops. The students' elaborations on the problems were limited, though. Obviously, the students' increased 
consideration of more problems with extratextual features might be linked with their exposure to text analysis activities in the workshops in which they were made aware of text features, particularly extratextual ones in translating.

\subsubsection{Difficulties related to general style conventions}

Difficulties with general style conventions were concerned with indicating the text types and conveying general stylistic features of the ST. This also covered the difficulties in deciding the formality of texts indicated by the choice of Vietnamese personal pronouns. The students' awareness of this type of issue seems to have allowed them to deal with problems at text level, particularly those related to style and/or choice of Vietnamese personal pronouns.

Before the workshops, six difficulties or problems related to general style conventions were raised. Four of the six problems mentioned were concerned with general differences in the writing style between English and Vietnamese authors (Student 6) or general assumptions about the text type (e.g., Students 3 indicated that the translation of the story should flow smoothly).

I have some difficulties when I must have the ability to approach and conversant with English texting style and then replace them into Vietnamese in the most suitable way to understand. (Student 6, Writ. 1)

Student 25 did not elaborate on their difficulty in translating "he" in Text $1 \mathrm{~b}$ : "After reading the whole text, I think Marcus is young boy, so I translate "he" into "cậu bé" [a neutral Vietnamese personal pronoun for a boy]" (Student 25, Writ. 1).

While prior to the workshops, only 6 problems and difficulties were reported without much elaboration, after the workshops, the students listed 16 problems and difficulties with general style conventions, focusing on specific text types and formality in translating personal pronouns. Some students categorised the texts as advertisements (Text 2a) or funny stories (Text 2b). This reporting which was not found in the pre-workshop written comments seems to have influenced their translation approaches after the workshops. For example, Student 13 said that they had difficulty in expressing the ST as an advertisement. Students 5, 15, and 24 found it hard to translate the humour of the ST (Text 2b).

How to translate in a funniest way cos' this is a funny story (Student 5, Writ. 2)

Text form: I guess it is an advertising. Don't know how to express it as an advertising. (Student 13, Writ. 2)

I am not good at making the translation to be funny (because this is a funny story). (Student 15, Writ. 2)

The students did not elaborate much on the role of specific text type conventions, which may be due to the lack of focus on these conventions during the workshops. However, after the workshops, students made more comments about the choice of personal pronouns which were relevant to text formality. The use of Vietnamese personal pronouns is subject to the text type and its degree of formality. For instance, in a formal speech or text (e.g., an editorial or a political speech), the pronoun "you" in English is equivalent to "quý vị" that indicates a distance between writer/speaker and reader/listener. Meanwhile, in an informal speech (e.g., a letter to a friend), "you" has the meanings of "bạn" or "cậu" which suggests a degree of informality of the text type. Those students 
$(3,4,16,19,24$, and 30) who referred to the problems in choosing the Vietnamese equivalents must have been aware of such differences in the use of personal pronouns in English and Vietnamese. They could have understood that English personal pronouns could be replaced with Vietnamese equivalents whose connotative meanings can be negative, positive, or neutral depending on the contexts of communication.

Use pronouns in Vietnamese, I use domestication when I translate but if in English the author used I - you, in Vietnamese, it may be "cậu - tôi", "nó - tôi". ["cậu - tôi" and "nó - tôi" are often used in informal situations but the latter sounds unfavourable] [Text 2b] (Student 19, Writ. 2)

Going one step further, some students explicitly discussed the appropriate choice of Vietnamese equivalents for English personal pronouns. A typical example was demonstrated by Student 30, who was conscious that the choice of certain Vietnamese words needed to take into account the content (i.e., the relationship of characters) in the story (Text $2 b)$. They were, therefore, concerned about the connotations of the Vietnamese pronouns.

Translate pronouns, objects adjectives nouns into $\mathrm{V}$ with negative meanings, attitude. Example: ... He/him: "nó", "hắn” or "anh ta" [For this student, these three Vietnamese equivalents were negative even though they may not be in other contexts]. (Student 30, Writ. 2)

After the workshops, the students listed problems with general style conventions three times more frequently than they had previously, with a greater focus on specific text types and formality in translating personal pronouns. They also provided more explanations for their difficulties with reference to specific text types, text formality, and content.

\subsubsection{Difficulties related to vocabulary and expressions}

The difficulties related to vocabulary and expressions referred to the students' comments about their comprehending and translating of vocabulary and expressions, such as idioms, metaphors, and similes. The problems they raised about vocabulary and expressions included:

- ST comprehension: The students had difficulty in understanding the meanings of vocabulary and expressions. They stated that they lacked vocabulary and did not know specific vocabulary items in the text.

- TT production: The students had difficulty in translating or finding Vietnamese translation words for vocabulary and expressions. The students wrote that even though they understood the vocabulary, they found it hard to translate.

- Both ST comprehension and TT production: The students mentioned both kinds of problems (comprehension and production) at the same time in one comment.

Before the workshops, the students mainly commented on linguistic problems and difficulties related to vocabulary and expressions (82 comments). Among these problems, those concerning the comprehension of vocabulary and expressions accounted for the largest portion, with 34 comprehension problems. Many students attributed their comprehension problems to their lack of knowledge of vocabulary and expressions. They noted that the words and phrases were "new", "strange," or "difficult" to them. Two students (19 and 29) attributed the comprehension problems to their lack of knowledge of the topic, while one student (25) said that they did not know what the pronoun "it" stood for in the sentence (this was concerned with grammatical knowledge). 
Missing the knowledge of environment so I don't know some words such as disposed, sharps [Text 1a]. (Student 29, Writ. 1)

Subject "it"- "it was as silent as the grave". I don't know if "it" refers to the house or refers to the atmosphere of the house [Text 1b]. (Student 25, Writ. 1)

After the workshops, the number of problems in comprehending vocabulary and expressions decreased to 20 problems. Some students also referred to their insufficient knowledge of vocabulary and expression. One student found it difficult to understand the meaning of the ST's figurative language rather than the words themselves. This showed a certain change in their comments about the ST language. In other words, they began to take into account implied meaning(s) in addition to the surface meanings of words.

Misunderstanding some images: I was on my own; wander like a dead leaf blown in the wind. (Student 6, Writ. 2)

In TT production, before the workshops some students said that it was difficult to find the appropriate Vietnamese equivalents as there were many definitions of each word.

Some vocabulary have many definition and I can't choice suitable one. For example: Eden, sharp, syringe. (Student 1, Writ. 1)

Only a few students provided explanations for their problems. Some students found the type of vocabulary to be problematic. For example, Students 4 and 5 said that the titles were difficult to translate, and Student 5 explained that translating titles requires "a large knowledge". Student 11 mentioned that translating titles was timeconsuming. Student 29 reported having difficulty translating the words that were repeated several times.
The words "I" and "he" repeat many times and I have to write it many times. (Student 29, Writ. 1)

After the workshops, many students also reported problems in translating or deciding on appropriate Vietnamese translation words for vocabulary and expressions, although they had no difficulty in comprehending their meanings.

I understand meaning of some phrases but I don't know to describe how to exact. (Student 18, Writ. 2)

Even thoughthenumberofproblemsrelated to vocabulary and expressions decreased from 82 to 70 , it remained the most commonly raised problem in Translation Task 2 after the workshops. However, the students noted fewer problems in comprehending vocabulary and expressions after the workshops, with only 20 comprehension problems raised compared with 34 before the workshops. This may also indicate that they learned that translation is not all about vocabulary, or they did not consider vocabulary comprehension problems worth noting even though they may still have had such problems. The students also rarely explained their difficulties in translating vocabulary and expressions before and after the workshops.

\subsubsection{Difficulties related to sentences and sentences structures}

Students also reported difficulties with sentences and sentence structures. They had difficulty in comprehending and translating the sentences. They discussed problems with the length of sentences or specific types of sentence structures, such as relative clauses or imperative structures. This category also covered students' mention of grammatical points in sentences, such as tenses and comparatives. The problems related to sentences and sentence structures included those in: 
- ST comprehension: The students had difficulty in understanding sentences and sentence structures.

- TT production: The students had difficulty in translating or finding Vietnamese translation words for sentences.

- Both ST comprehension and TT production: The students mentioned both kinds of problems (comprehension and production) at the same time in one comment.

The total number of responses from the students before the workshops was 13, which was slightly lower than the number reported after the workshops: 18. Firstly, there were similarly low numbers of problems cited in comprehension before and after the workshops ( 3 items before and 2 after). Before the workshops, Students 2 and 6 mentioned their difficulties comprehending sentence meanings without offering reasons for their lack of comprehension.

I don't understand the implication of some sentences in the text such as "There was... a bare floor”. (Student 6, Writ. 1)

After the workshops, Students 9 and 25 , who were the only two students to write about difficulties in understanding sentences and sentence structures, elaborated a little on their lack of sentence comprehension. They referred to sentential structures (e.g., "Not a thing" and "I was on my own", Student 9) and content (Student 25).

"Anyone... who spoke to me was in his bad books". I am not sure of what the sentence says: "because these people spoke to me, they were added in his bad books or these people were in his bad book, they weren't scare and they spoke to me". (Student 25, Writ. 2)

A similar number of difficulties ( 9 before and 7 after) were reported in relation to TT production and both ST comprehension and TT production. Before the workshops, the students expressed their uncertainty about the stylistic aspects of sentences, referring to the type of sentence structure (e.g., imperative sentences, Student 3 and passive sentences, Student 24), and the sentence length (e.g., short and reduced sentences, Students 14 and 15). Student 3 explained that they did not know whether the sentence was a piece of advice or an order and Student 25 thought that replicating the English use of passive sentences would be strange in translating into Vietnamese.

Translating some sentences is short. (Student 14, Writ. 1)

Passive structure-... I translate them into active but it doesn't seem logical, e.g., syringes and must be disposed of in special sharp bin. (Student 25, Writ. 1)

After the workshops, some students were more attentive to the problems caused by the length and complexity of sentences. A sentence being too long or too short could pose difficulties for the students (Students 3, 26, and 20):

Some sentences make me confuse when translating because it's too long and I find it extremely hard for me to punctuate the meaning of these sentences. (Student 26, Writ. 2)

The short sentence "Not a thing". (Student 20, Writ. 2)

Some other students wrote about their problems with special structures (Student 9) and complex sentences (Students 3, 11, 20, 19, and 30). Student 19 noted a problem with a relative clause.

Sentence structure; relative clause. (Student 19, Writ. 2)

Complex/compound sentence. (Student 30, Writ. 2) 
The students wrote small numbers of ST comprehension and TT production problems before and after the workshops. Even though after the workshops, the total number of students' responses about difficulties related to sentences and sentence structures was slightly higher than before the workshops, they rarely explained why the problems existed (as evidenced by the nine unspecified difficulties).

\subsection{Focus shifted to non-linguistic translation problems}

Before the workshops, the majority of students were focused on linguistic problems concerning vocabulary and sentence structures. They frequently noted difficulties in comprehending these features and producing target language expressions. Focusing on linguistic problems appears to be common among foreign language learners when they translate regardless of their communicative language teaching or structural language programs as evidenced in many studies including those by Lörscher (2005) and Tirkkonen-Condit (2005). These studies show that foreign language learners tend to translate local ST items, such as words and phrases, without paying much attention to the contextualised meanings which are implied by the surrounding sentences and extratextual textual features (e.g., the author and readers). Likewise, in this study, the students' greatest concern before the workshops was whether they understood words and phrases and how to render them into the target language. Accordingly, the small proportion of nonlinguistic problems (those with extratextual features and general style conventions) in the total number of identified problems before the workshops (12 out of 107) was small.

However, after the workshops, the students began to shift their focus from linguistic problems to non-linguistic ones as demonstrated by the slight decrease in identified problems with vocabulary structures and the surge in those with extratextual features and general style conventions (See Table 1). One reason for the decline in the students' identified linguistic problems could be that after the workshops the students found linguistic problems self-evident at their levels and that these problems were not worth noting. Furthermore, as the students noted fewer problems in comprehending vocabulary and expressions, it is likely that they resolved some of their comprehension problems by referring to text features as illustrated in the workshops. Meanwhile, after the workshops, more students identified pragmatic problems in dealing with "green cleaning" (Title 2a) when they were concerned about whether their translations satisfied the reader's comprehension and/or the operative function of the text.

Fernández and Zabalbeascoa (2012a, 2012b) have indicated that students who reported more non-linguistic problems (or those with general style conventions) performed better in translation than those who did not. In this study, the students diverted their attention from linguistic problems to non-linguistic problems and took into account text features presented in the workshops including extratextual and intratextual features (particularly non-linguistic extratextual ones). They began to consider problems with contextualised or pragmatic meanings determined by extratextual features while translating. This indicates that common behaviours of foreign language learners in problem identification can be changed if they are more aware of text features that influence ST comprehension and TT production

Overall, while the students did not note problems and difficulties with linguistic 
features as frequently as before, they paid more attention to those with extratextual features and the text type. This change in the students' awareness of translation problems would possibly lead to changes in their translation solutions will be examined in the next section.

\subsection{Students'translation solutions to titles}

This article only focuses on comparing students' translation solutions to the Title 1a, Text 1a ("Easy Recycling, Create your own Eden") and Title 2a, Text 2a ("Easy Green Cleaning, Create your own Eden"). Before the workshops, many students replaced "Eden" which appeared in both the titles with one of many idiomatic Vietnamese equivalents found in the dictionary including "thiên đường" or "vườn địa đàng" [heaven]. However, very few students explained their choices. Student 28 produced the TT "thiên đường" for the ST "Eden". It was not clear why Student 28 chose that as a solution and nor was it clear how they understood the purpose of the ST because the student only briefly wrote "the purpose of this text, 'create your own Eden"”.

After the workshops, many students also used similar Vietnamese equivalents for Eden as they did before; however, they could have considered the reader and/or other text features even though the evidence for their justifications was limited from their written comments. Typically, students avoided too much dependence on the ST form and focused on the ST message: "Vệ sinh dễ dàng - Làm cho cuộc sống dễ dàng hơn [Clean easily Make your life easier]" (Student 26). This certainly resulted from their attention to the reader. They wrote: "I don't know how to translate the title for Vietnamese people understood by Vietnamese thought" (Student 26, Writ. 1).
Furthermore, after the workshops, the students had varied solutions to "green cleaning”. Some students $(5,8,23,28,29$, and 30) produced the literal Vietnamese translation or kept the ST English form in their translations. Some of them possibly thought that Vietnamese readers would understand this English phrase. Students 4 and 19 commented that they retained the English ST "green cleaning" in their Vietnamese translations due to that Vietnamese communities in Australia might understand it (despite this, Student 19 used a sense-oriented translation solution in their translation).

Rather than being constrained by wordfor-word translation, some students $(7,10$, $11,15,16,17,18,19,20,21$, and 25), which was more than one-third of the 30 students, conveyed the sense of "green cleaning", and related "green cleaning" to "the environment" in their translations. Students 11, 15, and 25 related the phrase to being "environmentally friendly" while Student 7 relied on a common Vietnamese expression used to indicate a clean environment ("xanh sạch đẹp" [green, clean and beautiful]). Student 16 related "green cleaning" to "safe cleaning". Not many of these students explained their translation solutions. Only Student 11 referred to text function and the reader in producing idiomatic translation solutions that focused on the ST message as found in the published translation.

Dọn dẹp một cách thân thiện với môi trường thật dễ dàng-Hãy tạo thiên đường của riêng bạn [Easy environmentally friendly cleaning-Create your own heaven]. (Student 11, Title 2a)

Lau chùi dễ dàng và thân thiện với môi trường-Hãy tạo nên thiên đường của chính bạn [Clean in an easy and environmentally friendly way-Create your own heaven]. (Student 15, Title 2a) 
Even though the students' translation solutions to Title $2 \mathrm{a}$ demonstrated their avoidance of word-for-word translation after the workshops, they were limited in their expression and accuracy. For example, Student 7's translation contained some redundancy (e.g., redundant words-"rất" [very] and "để" [for the purpose of]). Other students (e.g., Students 13 and 21) distorted the meaning of the title. For example, in dealing with "green cleaning", Student 13 translated the phrase as "dọn dẹp cây cỏ" [bush and grass clearing] which did not convey the meaning of the original. Some students translated "green cleaning" literally and omitted or distorted its meaning, possibly due to their lack of ability or their own strategy.

Regardless of the students' limited expressionand accuracy, more than one-third of the 30 students produced translation solutions that focused on the ST message of "green cleaning" after the workshops. The analysis of the titles showed some students' attempts to avoid word-for-word translation and produce more idiomatic translation solutions, paying attention to extratextual features including text function and reader. Some also referred to these features in their word-for-word translation or ST form retention. Generally, the students began to produce informed and functionally appropriate translations regardless of their types of translation. This change in the students' translation production was possibly due to their increased attention to the problems with extratextual features including text function and the reader.

\section{Conclusion}

The study attempted to incorporate elements of the functional approach to translation in a series of workshops to enhance students' awareness of translation problems. The study particularly explored differences in students' identification of translation problems before and after the workshops. The results demonstrated a moderate change in their elaboration on translation problems and difficulties. The greatest proportion of the commentary was devoted to linguistic problems with vocabulary and expressions in both translation tasks. Notably, vocabulary comprehension problems had a considerable reduction, which contributed to the slight decrease in difficulties concerning vocabulary and expressions. In fact, the amount of commentary in other categories of problems increased significantly, especially the non-linguistic problems (extralinguistic problems and difficulties related to extratextual features and general style conventions). The non-linguistic problems accounted for a small number in Translation Task 1 before the workshops. However, they increased by approximately three to four times in the postworkshop translation task, with the extratextual features-related problems becoming the secondlargest category. The students' consideration of difficulties related to sentences and sentence structures did not change much. Despite this, after the workshops some students related their problems to not only sentence structure but also to content (an intratextual, non-linguistic feature).

The change in students' problem identification might be strongly linked with the fact that nearly one-third of the students produced translations based on informed decisions in consideration of text features, particularly extratextual ones. Despite the limited data on students' translation solutions, it was possible to claim that after the workshops, some students were able to deal with linguistic and extralinguistic difficulties (e.g., those with "green cleaning", Title 2a) by presenting translation solutions that incorporated what they had learnt in the workshops. 
It is necessary for teachers and students in translation courses to understand that they will have an understanding that language use in translation is influenced by a range of factors such as extratextual features. Students will be then less focused on the idea of language as a linguistic code. Students' sociolinguistic awareness of language needs to be enhanced so that linguistic problems are not their only focus. As a result, they can identify a wide range of problems related to extratextual features and text type conventions. The adequate attention of these problems will allow students to avoid too literal translation and make informed decisions in translating. Generally, elements of the functional approach to translation including text analysis and translation briefs should be included in tertiary English programs to develop students' strategic competence in particular and their translation competence in general.

This study is only limited to translation problem identification and the exploration of students' written reflections on their translations. An evaluation of students' performance in translation is, therefore, still missing. Future research can focus on other issues in teaching translation including students' translation competence and the link between their problem identification and translation competence.

\section{References}

Avval, S. F. (2013). Teaching translation: A look at the way it is in Iranian universities and the way it should be. Translation Journal, 16(3).

Chen, Q. (2010). The application of text type in nonliterary translation teaching. Translation and Interpreting Studies, 5(2), 208-219.

Carreres, Á., \& Noriega-Sánchez, M. (2011). Translation in language teaching: Insights from professional translator training. The Language Learning Journal, 39(3), 281-297. doi: 10.1080/09571736.2011.567356

Colina, S., \& Lafford, B. A. (2018). Translation in Spanish language teaching: The integration of a "fifth skill" in the second language curriculum. Journal of Spanish Language Teaching, 1-14. doi: 10.1080/23247797.2017.1407127

Cook, G. (2010). Translation in language teaching: An argument for reassessment. Oxford: Oxford University Press.

Fernández, F., \& Zabalbeascoa, P. (2012a). Correlating trainees' translating performance with the quality of their metacognitive self-evaluation. Perspectives: Studies in Translatology, 20(4), 463-478. doi: 10.1080/0907676X.2011.629730

Fernández, F., \& Zabalbeascoa, P. (2012b). Developing trainee translators' strategic subcompetence through metacognitive questionnaires. Meta: Journal des Traducteurs/Translators' Journal, 57(3), 740-762.

Gile, D. (2004). Integrated problem and decision reporting as a translator training tool. The Journal of Specialised Translation, 2, 2-20.

Gile, D. (2009). Basic concepts and models for interpreter and translator training (Rev. ed.). Amsterdam: John Benjamins Publishing.

González-Davies, M. \& Scott-Tennent, C. (2005). A problem-solving and student-centred approach to the translation of cultural references. Meta: Journal des Traducteurs/Translators' Journal, 50(1), 160179. doi: 10.7202/010666ar

Ho, P. V. P., \& Bui, P. T. K. (2013). Senior students' reports on their translation and interpretation abilities, teaching methods, and curriculum at Ho Chi Minh Open University. Journal of Science Ho Chi Minh City Open University, 1(6), 68-77.

Károly, A. (2014). Translation in foreign language teaching: A case study from a functional perspective. Linguistics and Education, 25, 90-107. doi: 10.1016/j.linged.2013.09.009

Kokkinidou, A., \& Spanou, K. (2013). The didactic use of translation in foreign language teaching: A practical example. In D. Tsagari \& G. Phlōros (Eds.), Translation in language teaching and assessment (pp. 173-190). Newcastle upon Tyne, UK: Cambridge Scholars Publishing.

Lee, V., \& Gyogi, E. (2018). Cultural-specific lexis for intercultural communication: Case studies from two different classrooms. Journal of Language, Identity \& Education, 1-15. doi: 10.1080/15348458.2017.1418357

Leonardi, V. (2010). The role of pedagogical translation in second language acquisition: From theory to practice. Bern: Peter Lang.

Leonardi, V., \& Salvi, R. (2016). Language pedagogy and translation studies: Towards a (re)definition of translation. In Y. Gambier \& L. van Doorslaer (Eds.), Border Crossings: Translation Studies and other disciplines (pp. 331-348). Amsterdam: John Benjamins Publishing.

Lörscher, W. (2005). The translation process: Methods and problems of its investigation. Meta: Journal 
des Traducteurs/Translators' Journal, 50(2), 597608. doi: 10.7202/011003ar

Nguyen, T. T. (2010). Nhu cầu người học và nhu cầu xã hội trong đào tạo cử nhân biên-phiên dịch tiếng Anh [Learners' needs and social needs in BA training in translation and interpreting]. Tạp chí Khoa hoc ĐHSP TP HCM. (22), 28-41.

Nord, C. (1997). Translating as a purposeful activity: Functionalist approaches explained. Manchester, UK: St. Jerome Publishing.

Nord, C. (2005). Text analysis in translation: Theory, methodology, and didactic application of a model for translation-oriented text analysis. Amsterdam: Rodopi.

Pham, H. H., \& Ton, N. N. H. (2007). Đào tạo chuyên ngành biên dịch trong thời kỳ mới: thách thức lớn cho các truòng đại hoc [Training of translation in the new era: great challenges for universities]. Paper presented at "Hội thảo công tác dịch thuật và đào tạo cử nhân" [Conference on Translation and Training], Hanoi, Vietnam. Retrieved from https://123doc.org//document/2592959-dao-taochuyen-nganh-bien-dich-trong-thoi-ky-moi-thachthuc-lon-cho-cac-truong-dai-hoc.htm

Pham, H. H., \& Tran, L. T. (2013). Developing graduate knowledge and skills for the world of work: The case of the translation curriculum in Vietnam. Language, Society and Culture. (36), 7-17.

Saleh, N. J., \& Weda, S. (2018). Indonesian poetry translation: The problem within. The Journal of English as an International language, 13(2.2), 64-87.

Schäffner, C., \& Wiesemann, U. (2001). Annotated texts for translation: English-German: functionalist approaches illustrated. Clevedon, UK: Multilingual Matters

Tirkkonen-Condit, S. (2005). The monitor model revisited: Evidence from process research. Meta: Journal des Traducteurs/Translators' Journal, 50(2), 405-414. doi: 10.7202/010990ar

Wongranu, P. (2017). Errors in translation made by English major students: A study on types and causes. Kasetsart Journal of Social Sciences, 38(2), 117-122. doi: 10.1016/j.kjss.2016.11.003

\title{
NÂNG CAO KHẢ NĂNG PHÁT HIỆN VẤN ĐỀ DỊCH THUẬT CỦA SINH VIÊN NGÀNH CỦ NHÂN ANH
}

\author{
Nguyễn Thị Thu Hướng \\ Trường Đại học Ngoại ngũ, Đại học Đà Nã̃ng \\ 131 Luơng Nhũ Hộc, Cẩm Lệ, Đà Nã̃ng, Việt Nam
}

Tóm tắt: Việc dạy môn dịch ở Việt Nam và một số nước thường hay tập trung vào các vấn đề ngôn ngữ và ít lưu ý đến quá trình dịch của sinh viên. Dựa trên cách tiếp cận chức năng trong dịch thuật, bài báo này nghiên cứu khả năng xác định vấn đề dịch thuật (thể hiện một phần năng lực dịch thuật) của sinh viên tham dự một khóa học dịch thuật tại một chương trình cử nhân tiếng Anh ở Việt Nam. Bài báo trình bày sự khác biệt trong khả năng xác định vấn đề dịch thuật của sinh viên thông qua việc so sánh nhận xét của sinh viên sau khi làm bài dịch và các giải pháp dịch thuật của sinh viên trước và sau các workshop về các vấn đề cơ bản trong dịch thuật. Kết quả nghiên cứu cho thấy sau workshop, sinh viên bắt đầu chú ý đến các vấn đề phi ngôn ngữ thay vì chủ yếu quan tâm các vấn đề ngôn ngữ như trước workshop. Các vấn đề phi ngôn ngữ bao gồm các vấn đề liên quan đến yếu tố ngoại văn bản và phong cách văn bản. Theo kết quả phân tích các giải pháp dịch tựa đề, sinh viên bắt đầu tránh cách dịch từ theo từ và dịch một cách phù hợp hơn. Bài báo đề xuất cần đưa các hoạt động phân tích văn bản và xác định vấn đề dịch thuật vào các khóa giảng dạy dịch thuật tại các trường ngoại ngữ.

Tù khóa: giảng dạy dịch thuật, quá trình dịch, vấn đề dịch thuật, xác định vấn đề dịch thuật, phân tích văn bản 